\title{
HUBUNGAN ASUPAN PROTEIN DAN ZAT BESI DENGAN KADAR HEMOGLOBIN
}

\author{
Nopiana, Kusdalinah, Meriwati \\ Politeknik Kesehatan Kementerian Kesehatan Bengkulu, Jurusan Gizi, \\ Jalan Indragiri Nomor 03 Padang Harapan Kota Bengkulu \\ kusdalinah_11@yahoo.com
}

\begin{abstract}
Diets of adolescents who always skip breakfast and lunch trigger nutritional problems in adolescence. Young women is one of the vulnerable groups that suffer from anemia. Nutritional Studies Program student DIII an example adolescent groups and also further prospective health workers who would not be exposed to nutritional problems, but based on a preliminary survey still found in hemoglobin levels below normal, the intake of protein and iron are also low. The purpose of this study was to determine the relationship of the intake of protein and iron in hemoglobin of Diploma Studies Student Nutrition Program MoH Bengkulu polytechnic 2014. The design of this cross-sectional study with random sampling method on 75 female students. The results showed no significant relationship between protein intake with hemoglobin levels ( $p$ $=0.005)$, in addition there is a relationship intake of iron with hemoglobin levels $(p=0.002)$. The intake of protein and iron associated with hemoglobin levels significantly.
\end{abstract}

Keywords: Intake Protein, Iron, Kadar Hemogloblin

\begin{abstract}
Abstrak: Pola makan remaja yang selalu melewatkan waktu makan pagi dan makan siang memicu terjadinya masalah gizi pada usia remaja. Remaja putri merupakan salah satu kelompok yang rawan menderita anemia . Mahasiswi Progam Studi DIII Gizi merupakan contoh golongan remaja lanjut dan juga calon tenaga kesehatan yang tentunya tidak terpapar dengan masalah gizi, namun berdasarkan survei awal masih ditemukan kadar hemoglobin dibawah normal, asupan protein dan zat besi juga rendah. Tujuan dari penelitian ini adalah untuk mengetahui hubungan asupan protein dan zat besi dengan kadar hemoglobin pada Mahasiswi Progam Studi DIII Gizi Poltekkes Kemenkes Bengkulu Tahun 2014. Desain Penelitian ini Cross Sectional dengan metode pengambilan sampel secara acak pada 75 orang mahasiswi. Hasil penelitan menunjukkan ada hubungan yang signifikan antara asupan protein dengan kadar hemoglobin $(p=0,005)$, Selain itu ada hubungan asupan zat besi dengan kadar hemoglobin $(p=0,002)$. Asupan protein dan zat besi berhubungan bermakna dengan kadar hemoglobin.
\end{abstract}

Kata Kunci : Asupan Protein, Zat Besi, Kadar Hemogloblin

Remaja merupakan aset bangsa untuk terciptanya generai mendatang yang baik. Masa remaja atau adolesence adalah waktu terjadinya perubahan-perubahan yang berlangsung cepat dalam hal pertumbuhan fisik, kognitif, dan psikososial atau tingkah laku. Usia remaja merupakan usia peralihan dari masa kanakkanak menuju masa remaja. Usia remaja dikategorikan menjadi remaja awal (10-14 tahun), remaja menengah (14-17 tahun) dan remaja lanjut (17-20). Perubahan-perubahan itu mempengaruhi kebutuhan gizi dan makanan mereka (Wirajatmadi, 2013).

Pola makan remaja yang selalu melewatkan waktu makan pagi dan makan siang memicu terjadinya masalah gizi pada usia remaja. Salah satu masalah gizi yang dialami oleh remaja yaitu anemia (Wirajatmadji, 2013). Anemia merupakan suatu keadaan ketika jumlah eritrosit (sel darah merah) atau kadar $\mathrm{Hb}$ dalam darah kurang dari normal, kadar $\mathrm{Hb}$ normal untuk remaja perempuan yaitu 12-14 $\mathrm{mg} / \mathrm{dl}$. Jika kadar $\mathrm{Hb}$ diketahui rendah maka dapat dikatakan bahwa remaja mengalami anemia (Gandasoebrata.2001).

Remaja putri merupakan salah satu kelompok yang rawan menderita anemia, karena itu sasaran progam penanggulangan anemia gizi telah dikembangkan pada remaja putri sederajat, sebagai upaya strategis dalam 
upaya memutus simpul siklus masalah gizi. Prevalensi anemia dikalangan remaja putri berjumlah 26,50\%. Hal ini mengindikasikan anemia masih menjadi masalah kesehatan di Indonesia (Tarwoto, Ns 2012).

Jenis anemia yang paling sering timbul adalah kekurangan zat besi, Berdasarkan Angka Kecukupan Gizi (AKG)) untuk asupan protein pada usia remaja lanjut (17-20 tahun) yaitu 59 g/orang/hari, sedangkan asupan zat besi pada remaja usia 17-20 tahun yaitu 13 mg/orang/hari Almatsier, 2010).

Protein dalam tubuh manusia berperan sebagai pembentuk butir-butir darah (hemopoiesis) yaitu pembentukan erytrocyt dengan hemoglobin di dalamnya. Di dalam tubuh, zat besi tidak terdapat bebas, tetapi berasosiasi dengan molekul protein membentuk feritin rendah (Almatsier, 2010).

Berdasarkan prevalensi anemia yang terjadi menurut WHO pada tahun 1993-2005 diketahui sebanyak 1,6 miliar orang, dan diperkirakan lebih dari $30 \%$ penduduk dunia yaitu 1500 juta orang menderita anemia (Lubis, 2002). Sedangkan data dari riskesdas pada tahun 2007 diketahui prevalensi anemia pada remaja putri di provinsi Bengkulu yang memiliki kadar $\mathrm{Hb}<12 \mathrm{~g} / \mathrm{dl}$ yaitu berjumlah 16,2\% (Riskesdas, 2007).

Anemia dapat menyebabkan lekas lelah, konsentrasi belajar menurun sehingga prestasi belajar rendah dan dapat menurunkan produktivitas kerja. Disamping itu anemia menurunkan daya tahan tubuh sehingga mudah terkena infeksi. Jika kejadian anemia pada remaja tidak tertangani dengan baik maka akan berlanjut hingga dewasa dan berkontribusi besar terhadap angka kematian ibu, bayi lahir prematur dan bayi dengan berat lahir rendah (Wirajatmadi, 2013).

Contoh golongan remaja lanjut adalah Mahasiswi Progam Studi DIII Gizi Poltekkes Kemenkes Bengkulu. Mahasiswi tersebut merupakan tenaga kesehatan yang memiliki tanggung jawab melayani masyarakat, sudah seharusnya mahasiswi tenaga kesehatan tidak terpapar oleh masalah gizi yang salah satunya yaitu anemia.
Berdasarkan survei awal yang telah dilakukan pada mahasiswi Progam Studi DIII Gizi Poltekkes kemenkes Bengkulu tersebut diperoleh 10 sampel, diketahui 3 diantaranya yaitu $30 \%$ mahasiswa dinyatakan anemia, dengan kadar $\mathrm{Hb}$ dibawah normal $(<12 \mathrm{mg} / \mathrm{dl})$, dan 7 diantaranya yaitu $70 \%$ mahasiswa dinyatakan kadar Hb normal (12-14 mg/dl).

Asupan protein dan asupan zat besi remaja yang diketahui melalui recall didapatkan hasil dari 10 sampel diketahui (40\%) remaja memiliki asupan protein dan asupan zat besi yang rendah dan (60\%) diantaranya memiliki asupan yang cukup.

Penelitian ini bertujuan untuk mengetahui hubungan asupan protein dan zat besi dengan kadar hemoglobin darah pada mahasiswi Progam Studi DIII Gizi Poltekkes Kemenkes Kota Bengkulu.

\section{BAHAN DAN CARA KERJA}

Desain yang digunakan yaitu bersifat obsevasional dengan pendekatan cross sectional, yang meliputi variabel independen (asupan protein dan asupan zat besi) dan variabel dependen (kadar hemoglobin). Populasi pada penelitian ini adalah seluruh mahasiswi DIII yang berusia 17-20 tahun di Progam Studi DIII Gizi Poltekkes Kemenkes Kota Bengkulu berjumlah 200 orang yang mencangkup tingkat I, II dan III.

Jumlah sampel penelitian sebanyak 75 orang yang diperoleh secara acak pada mahasiswi Prodi DIII Gizi Poltekkes Kemenkes Bengkulu mencangkup tingkat I, II dan III. Data asupan protein dan asupan zat besi mahasiswa diperoleh dengan metode Food Recall dengan menggunakan form recall $3 \mathrm{x}$ 24 jam, sedangkan data kadar hemoglobin darah mahasiswa diperoleh menggunakan uji sahli melalui tenaga analis kesehatan

\section{HASIL}

Tabel 1 menunjukkan asupan protein makanan mahasiswi rata-rata adalah 58,6 g dengan asupan terendah yaitu 19,8 g dan tertinggi yaitu 83,7 g, Sedangkan asupan zat besi makanan mahasiswi rata-rata adalah 14,07 mg dengan asupan terendah yaitu 6,81 mg dan 
tertinggi yaitu 27,0 mg. Berdasarkan Uji normalitas data bahwa semua variabel asupan protein, asupan zat besi dan kadar hemoglobin yang terdistribusi normal dengan nilai $p>0,05$. Selanjutnya data bisa dianalisis dengan uji Korelasi Pearson.

Tabel 1. Gambaran Asupan Protein dan Zat Besi dengan Kadar Hemoglobin pada Mahasiswi Progam Studi DIII Gizi

\begin{tabular}{ccccc}
\hline Variabel & Mean & SD & Min & Max \\
\cline { 1 - 2 } $\begin{array}{c}\text { Asupan } \\
\text { Protein (g) }\end{array}$ & 58,6 & 11,6 & 19,8 & 83,7 \\
$\begin{array}{c}\text { Asupan Zat } \\
\text { besi (mg) } \\
\text { Kadar Hb } \\
\text { (mg/dl) }\end{array}$ & 14,07 & 4,13 & 6,81 & 27,0 \\
\hline
\end{tabular}

Tabel 2 menunjukkan bahwa ada hubungan antara asupan protein dengan kadar hemoglobin pada Mahasiswi Program Studi DIII Gizi Poltekkes Kemenkes Bengkulu, artinya semakin besar asupan protein maka semakin besar kadar hemoglobin pada Mahasiswi Progam Studi DIII Gizi Poltekkes Kemenkes Bengkulu. Dari hasil uji statistik didapatkan ada hubungan yang bermakna, dengan menggunakan uji korelasi pearson untuk asupan protein dengan kadar hemoglobin didapatkan ada hubungan yang kuat dengan nilai $r=0,506$ hal ini juga ditunjukkan pada $\mathrm{p}$ $=0,005$.

Tabel 2 Hubungan Asupan Protein dengan Kadar Hemoglobin pada Mahasiswi Progam Studi DIII Gizi

\begin{tabular}{lccc}
\hline \multicolumn{1}{c}{ Variabel } & n & $\boldsymbol{r}$ & $\boldsymbol{p}$ \\
\hline $\begin{array}{l}\text { Asupan protein } \\
\text { dengan kadar } \\
\text { hemoglobin }\end{array}$ & 75 & 0,506 & 0,005 \\
$\begin{array}{l}\text { Asupan zat besi } \\
\text { dengan kadar } \\
\text { hemoglobin }\end{array}$ & 75 & 0,358 & 0,002 \\
\hline
\end{tabular}

Tabel 2 menunjukkan bahwa ada hubungan antara asupan zat besi dengan kadar hemoglobin pada Mahasiswi Progam Studi DIII Gizi Poltekkes Kemenkes Bengkulu, artinya semakin besar asupan zat besi maka semakin besar kadar hemoglobin pada Mahasiswi Progam Studi DIII Gizi Poltekkes Kemenkes Bengkulu. Dari hasil uji statistik didapatkan ada hubungan yang bermakna, dengan menggunakan uji korelasi pearson untuk asupan zat besi dengan kadar hemoglobin didapatkan ada hubungan yang lemah dengan nilai $r$ yaitu 0,358 . hal ini juga ditunjukkan pada $p=0,002$.

\section{PEMBAHASAN}

\section{Asupan Protein}

Berdasarkan hasil uji korelasi pearson bahwa ada hubungan yang signifikan antara asupan protein dengan kadar hemoglobin pada mahasisiwi Prodi D III Poltekkes Kemenkes Bengkulu tahun 2014. Penelitian ini sejalan dengan penelitian yang telah dilakukan oleh Andarina (2006) tentang Hubungan Konsumsi Protein Hewani dan Zat Besi dengan Kadar Hemoglobin pada Balita Usia 13-36 Bulan.

Protein berfungsi sebagai pembentuk ikatan ikatan esensial tubuh meliputi hormonhormon seperti tiroid, insulin, epinefrin, dan berbagai enzim lain bertindak sebagai katalisator atau membantu perubhan-perubahan biokimia yang terjadi didalam tubuh. Hemoglobin, atau pigmen darah yang berwarna merah berfungsi sebagai pengangkut oksigen dan karbondioksida akan diangkut oleh protein (Almatsier, 2010).

Asupan protein yang adekuat sangat penting untuk mengatur integitas, fungsi dan kesehatan manusia dengan menyediakan asam amino sebagai precursor molekul esensial yang merupakan komponen dari semua sel dalam tubuh.

\section{Asupan Zat Besi}

Berdasarkan uji korelasi pearson diperoleh ada hubungan yang bermakna antara asupan zat besi dengan kadar hemoglobin Bengkulu pada mahasisiwi Prodi D III Poltekkes Kemenkes Bengkulu tahun 2014. Hasil Peneliltian ini sejalan dengan yang dilakukan oleh Arifin SU (2013) tentang hubungan asupan zat gizi dengan kejadian anemia pada Anak Sekolah Dasar di Kabupaten Bolaang Mongondow Utara.

Hasil penelitian ini tidak sejalan dengan yang dilakukan oleh Wibowo dan Yulianti (2013) bahwa tidak ada hubungan antara asupan zat besi melalui suplemen terhadar 
kadar hemoglobin pasien GGK, dikarena pasien GGK banyak kehilangan darah selama perawatan

Keterkaitan zat besi dengan kadar hemoglobin dapat dijelaskan bahwa besi merupakan komponen utama yang memegang peranan penting dalam pembentukan darah (hemotopoiesis), yaitu mensintesis hemoglobin. Kelebihan besi disimpan sebagai protein feritin, hemosiderin di dalam hati, sumsum tulang belakang, dan selebihnya didalam limpa dan otot. Apabila simpanan besi cukup maka kebutuhan untuk pembentukan sel darah merah dalam sumsum tulang akan terpenuhi (Almatsier,2010).

Jumlah simpanan zat besi berkurang dan jumlah zat besi yang diperoleh dari makanan yang rendah, maka tidak terjadi ketidakseimbangan zat besi didalam tubuh, akibat nya kadar hemoglobin menurun dibawah batas normal yang di sebut sebagai anemia zat gizi.

Tidak adanya hubungan antara asupan zat besi dengan kadar hemoglobin dikarenakan adanya faktor lain seperti banyak kekurangan darah yang di akibatkan kurangnya asupan zat

\section{DAFTAR RUJUKAN}

Almatsier, Sunita. 2004. Prinsip dasar ilmu Gizi. Jakarta :PT Gamedia Jakarta

Arifin, SU, Nelly Mayulu, Julia Rottie; Hubungan Asupan Zat Gizi Dengan Kejadian Anemia Pada Anak Sekolah Dasar Di Kabupaten Bolaang Mongondow Utara. (ONLINE), ejourejournal.unsrat.ac.id/index.php/jkp/article.diakses tanggal 13 Desember 2013

D. Andarina, Hubungan Konsumsi Protein Hewani dan Zat Besi dengan Kadar Hemoglobin pada Balita Usia 13-36 Bulan.(ONLINE). journal.unair.ac.id/filerPDF/Naskah, diakses tanggal 15 Desember 2013. besi yang akan mempengaruhi rendahnya kadar hemoglobin.

\section{KESIMPULAN}

Berdasarkan hasil penelitian yang telah dilakukan pada Mahasiswi Progam Studi DIII Gizi Poltekkes Kemenkes Bengkulu tahun 2014 maka dapat disimpulkan bahwa: (1) Asupan protein rata-rata 58,6 g dan nilai protein ini masih kurang dari AKG yaitu $62 \mathrm{~g}$. Asupan zat besi rata-rata $14,0 \mathrm{mg}$ dan nilai zat besi ini masih kurang dari AKG yaitu $26 \mathrm{mg}$. (2) Hasil pengukuran kadar hemoglobin ratarata mahasiswi adalah 12,0 $\mathrm{g} / \mathrm{dl}$,sedangkan berdasarkan nilai normal kadar hemoglobin untuk remaja putri adalah $12 \mathrm{~g} / \mathrm{dl}-14 \mathrm{~g} / \mathrm{dl}$. (3) Ada hubungan yang bermakna antara asupan protein dengan kadar hemoglobin dan (4) Ada hubungan yang bermakna antara zat besi dengan kadar hemoglobin.

Disarankan perlunya kesadaran mahasiswi untuk menjaga pola makan dengan gizi seimbang guna menjaga kesehatan terutama megkonsumsi sumber protein hewani.

Gandasoebrata. 2001. Penuntun Laboratorium Klinik. Jakarta: Penerbit Dian Rakyat

Riskesdas. 2007. Riset Kesehatan Dasar.Indonesia.

Tarwoto NS, et al. 2012. Kesehatan Remaja Problem dan Solusinya. Jakarta: Selemba Medika

Wibowo dan Yulianti. Hubungan asupan Zat besi, Vitamin A dan Vitamin C, Dengan Kadar Hemoglobin Penderita gagal ginjal Kronik Hemodialisis di RSUP DR.Soeradji Tirtonegoro.Klaten.Jurnal diakses pada tanggal 9 desember 2013.

Wiratmadji. 2013. Peranan Gizi Dalam Daur Kehidupan..Jakarta:Rineka 